\title{
PENGARUH BRAND IMAGE, PRODUCT KNOWLEDGE DAN CONSUMER PERCEPTION TERHADAP PURCHASE INTENTION LEMARI ES MEREK SHARP DI KECAMATAN MENGANTI-GRESIK
}

\author{
SUPARLAN \\ Program Studi Manajemen \\ Fakultas Ekonomi Universitas Muhammadiyah Gresik \\ Kampus GKB, Jl Sumatra 101 GKB Gresik 61121 Jawa Timur Indonesia \\ e-mail : Alan.kembang14@yahoo.com
}

\begin{abstract}
ABTRACT
With the knowledge of quality brand with a refrigerator and then the man will get to choose where the refrigerator was in accordance with her wishes. Fridge was a household electrical appliance that uses refrigeration (cooling process) to help food preservation. The purpose of this study was to analyze the influence of partial and simultaneous Brand image, Consumer Product Knowledge and Perception to purchase intention in the District of Sharp refrigerator Menganti Gresik. Some of the variables as indicators of Brand image, Consumer Product Knowledge and Perception among other brands, the price benefits, quality, efficient, model, pengoprasian, sales price affect the Purchase Intention in Menganti Gresik district. The analysis tools was to use multiple linear regression with the help of SPSS/Windows.V.15. hypothesis testing used $t$ test and $F$ test, both at a significant level of $5 \%$. Calculation results showed that the three variables were included in the analysis together had a significant effect on Purchase Intention in Menganti Gresik district. This conclusion was based on results that showed the value of $F$ perhitunggan count of 5.787 over $2.699 F$ table of the three variables, it appeared Consumer Perception had a significant influence calculated $t$ value of 2.489 with a significance level of $0.025 \%$. Based on the results of the analysis was the Purchase Intention in the district of Gresik Menganti very dominant towards Consumer Perception, Consumer Perception of the three variables should be further enhanced so that consumers understand more Brand image, Consumer Product Knowledge and Perception of Purchase intention.
\end{abstract}

Keywords: Brand image, Product Knowledge, Consumer Perception, Purchase intention.

\section{PENDAHULUAN}

Dengan pengetahuan kualitas merek suatu lemari es maka manusia akan bisa memilih mana lemari es yang sesuai dengan keinginannya. Lemari es adalah sebuah alat rumah tangga listrik yang menggunakan refrigeration (proses pendingin) untuk menolong pengawetan makanan. Sebagian masyarakat di seluruh Indonesia memiliki lemari es. Refrigrasi bekerja menggunakan pompa panas pengubah fase beroperasi dalam sebuah putaran refrigeration. Lemari es industri digunakan untuk kebutuhan industri, seperti di restoran atau supermarket. Perkembangan teknologi sekarang ini semakin canggih, segala sesuatunya dapat dilakukan dengan sistem otomatis, dimana sistem ini dapat dikembangkan dengan berbasis komputer dan mikrokontroller.

Merek (Brand) bukanlah sekedar nama, istilah (term), tanda (sign), simbol atau kombinasinya. Merek adalah janji perusahaan secara konsisten untuk memberikan features, benefit dan services pada pelanggan. Janji inilah yang membuat masyarakat mengenal merek tersebut lebih mengenal merek yang lain (Stanton dan Futrell, 1989, Keagan 1992; Aeker, 1991dalam Muafi, usahawan; 2002,44). Kenyataanya, saat ini karakteristik unik dari pemasaran modern bertumpu pada penciptaan merk-merk yang bersifat pembedaan (different) sehingga dapat memperkuat image perusahaan dan produk dalam benak konsumen.
Merek yang prestisius dapat dikatakan merk yang memiliki brand image (citra merek) yang kuat karena sumber citra merek adalah dari persepsi konsumen (Kotler, 1993 dalam Lassar, Mittal dan Shahma, 1995:12). Di pasar yang serba kompetitif seperti sekarang ini, merek mempunyai peranan penting bagi kelangsungan hidup sebuah perusahaan. Apalagi pemasaran di masa yang akan datang lebih menjadi persaingan antar merek, yaitu persaingan untuk merebut konsumen melalui merek. Merek bukan hanya dianggap sebagai sebuah nama, logo ataupun simbol. Lebih dari itu merek merupakan nilai yang ditawarkan sebuah produk bagi konsumen yang memakainya.

Kotler dan Keller (2007) menyatakan bahwa merek sebenarnya merupakan sarana untuk membedakan barang-barang dari satu produsen dengan produsen yang lain. Bahkan pada tataran yang lebih tinggi merek menurut Kotler dan Keller (2007) dapat memainkan sejumlah peran penting untuk meningkatkan hidup konsumen dan nilai keuangan perusahaan, dengan kata lain bahwa merek dapat menjadi sumber penghidupan perusahaan karena itu merek merupakan salah satu keputusan strategis yang harus diperhatikan oleh perusahaan. Kotler dan Keller (2007) menyatakan bahwa merek dapat menjadikan satu tingkat tertentu dimana pembeli yang puas dapat lebih mudah memilih produk tersebut. Merek dapat memberikan manfaat yang besar bagi produsen 
maupun konsumen bagi konsumen merek mampu menambah nilai bagi konsumen. Berdasarkan hal tersebut peneliti memilih variabel Brand Image karena merek merupakan hal yang dilihat pertama kali oleh konsumen sehingga harus diperhatiakn terlebih dahulu.

Peneliti memilih produk lemari es Sharp karena dari segi pemasarannya sangat baik terbukti dengan jumlah konsumenya yang mencapai 8.400 responden tersebar di enam kota besar di Indonesia seperti Jakarta, Bandung, Semarang, Surabaya, Medan dan Makasar. (Radar Cirebon) dan omzetnya mencapai Rp 35 miliar per bulan dari sebelumnya hanya mematok Rp 25 miliar per bulan. (Suara Merdeka Cetak).

PT Sharp Electronics Indonesia (SEID) kembali memanjakan pelanggannya dengan meluncurkan serangkaian produk terbaru lemari es premium Plasmacluster yang didesain dan dibuat khusus dengan fitur bagi kepentingan konsumen Indonesia.

SEID meluncurkan dua seri terbarunya,yaitu seri Vetro dan seri King Samurai. Seri Vetro mengusung konsep lemari es yang stylish, hemat, segar, dan berteknologi canggih (hightech). Dibalut dengan desain elegan serta sudut yang membulat bergaya anggun bak bangsawan Eropa yang futuristik serta tampak luar pintu lemari es yang glossy dengan bentuk modern menciptakan tampilan stylish pada lemari es ini.

Keunikan seri Vetro terdapat pula pada desain handlenya, yaitu CylinderStainless Steel Handle, handle berbentuk silinder diaplikasikan sepanjang bodi lemari es memungkinkan konsumen dapat membuka dan menutup lemari es secara mudah walau dengan beban yang berat. Seri Vetro juga mengedepankan ramah lingkungan dan hemat energi dengan pengaplikasian fitur-fitur pendukung, seperti lampu LED yang menghasilkan pencahayaan yang terang dan kemewahan tersendiri pada tampilan interior lemari es ini yang telah mendapat posisi A untuk konsumsi energinya (standar Eropa).

Herdiana A Pisceria (SEID Product Marketing GM) mengatakan, konsumen tidak perlu khawatir dengan kesegaran makanan dan minuman yang disimpan di dalam lemari es Vetro. 'Karena dilengkapi dengan teknologi ion Plasmacluster. Teknologi tersebut mampu menghasilkan ion positif dan negatif yang efektif menonaktifkan bakteri, virus, serta menghambat perkembangan jamur, makanan pun akan lebih segar,sehat,dan tahan lebih lama, konferensi pers di Jakarta,2009 April.

Peristiwa mengatakan bahwa, terdapat pula teknologi hybrid cooling system dengan sistem pendinginan yang merata, menjaga tingkat pendinginan dan kelembapan lemari es. Ditambah dengan teknologi Nano Deodorizer, yaitu molekul deodorizer yang berukuran nano dapat mengurangi bau tidak sedap pada lemari es agar makanan awet dan selalu segar selama disimpan Selain itu, disediakan juga teknologi touch panel control, yaitu fitur unik layar sentuh yang mempermudah pengaturan temperatur dan eco saving function, juga dilengkapi dengan door alarm untuk mengingatkan bila pintu terbuka terlalu lama sehingga konsumen dapat menghemat biaya dan energi.

SEID juga menghadirkan kembali lemari es dengan seri Samurai. Kini Sharp meluncurkan seri lemari es Samurai terbaru, yaitu King Samurai. Lemari es berkapasitas lebih besar yang mampu memuat beragam kebutuhan keluarga dengan konsep stylish, hemat, dan segar. King Samurai yang stylish dilengkapi dengan keunikan Katana handle (berupa gagang pedang pendekar samurai) yang mantap digenggam ketika konsumen membuka atau menutup lemari es.

Desain pintunya mewah dan elegan. Hemat energi ala King Samurai diwujudkan dengan pengaplikasian lampu LED yang memberikan pencahayaan terang dan mewah, namun dengan konsumsi listrik yang rendah. Kesegaran makanan pun akan tetap terjaga karena King Samurai didukung dengan teknologi istimewa dari Sharp, yaitu Plasmacluster yang dapat menonaktifkan virus, bakteri, dan kuman.

"Saat ini Sharp telah menguasai 33\% market share lemari es. SEID yakin, dengan kedua seri terbaru tersebut, lemari es Sharp akan dapat merebut 35\% pangsa pasar lemari es sekelasnya," ungkap Andrew Gultom, Home Appliances Product Manager SEID. ( Harian Seputar Indonesia).

Sharp Electronics Indonesia telah memulai perjalanan panjangnya di Indonesia sejak tahun 1970. SEID bermula dari PT Yasonta, yang didirikan pada tahun 1970 sebagai perusahaan nasional. Pada 1994, Sharp Corporation menjadikan PT Yasonta perusahaan patungan PMA dengan mengakuisisi PT Yasonta Shares dan mengubah namanya menjadi PT Sharp Yasonta Indonesia (SYI). SYI adalah perusahaan manufaktur yang memproduksi produk elektronik konsumen: televisi berwarna dan produk audio seperti komponen mini, home theater, dan radio kaset. Peralatan listrik rumah seperti lemari es. Diharapkan dengan dikenalnya sharp sebagai lemari es maka akan mengangkat respon dari konsumen untuk membeli lemari es sharp tersebut.

Penelitian terhadap brand image (citra merek) yang akan mendukung keberhasilan pengetahuan produk dalam memasuki pasar, ini didukung dengan melakukan penelitian pada persepsi konsumen dalam melakukan pembelian. Diharapkan data yang diperoleh dapat menjawab permasalahan dari penelitian ini. Fakta membuktikan bahwa gencarnya iklan yang dilakukan oleh merek sharp menunjukkan betapa besar keinginan merek sharp untuk berhasil dalam pengetahuan produk. Persepsi adalah proses yang digunakan oleh individu untuk memilih, mengorganisasi, dan menginterpretasi masukan informasi guna menciptakan gambaran dunia yang memiliki arti. Persepsi tidak hanya bergantung pada rangsangan fisik tetapi juga pada rangsangan yang berhubungan dengan lingkungan sekitar dan keadaan individu yang bersangkutan (Kotler, 2005). Peneliti 
memilih variabel Product Knowledge karena pengetahuan produk merupakan salah satu alat promosi dari perusahaan yang berupa brosur yang dibagikan kepada konsumen, sedangkan alasan peneliti memilih variabel Consumer Perception karena persepsi konsumen terhadap produk yang berbeda-beda sehingga perlu duadakan penelitian mengenai variabel Consumer Perception tersebut.

Peneliti memilih lokasi penelitian di Kecamatan Menganti Gresik karena lokasinya yang strategis, mudah terjangkau dan berdekatan dengan wilayah kota surabaya sehingga dapat lebih mudah dalam maencari informasi tentang produk lemari es merek sharp melakukan.

\section{TINJAUAN PUSTAKA}

\section{Citra Merek (Brand Image)}

Konsumen memiliki kecenderungan untuk membentuk citra atau membuat gambaran atau membuat suatu pencitraan tentang merek, toko maupun perusahaan berdasarkan inference yang mereka bentuk dari stimuli pemasaran maupun enviromental stimuli. Assael (19995:212) mendefinisikan citra sebagai berikut "An image is total perception of the object that consumers from by processing information from various sources overtime”. Artinya sebuah citra adalah persepsi total tentang suatu objek yang dibentuk oleh konsumen dengan memproses informasi dari berbagai sumber dari waktu ke waktu.

Assael (1995:213) adalah: “ Brand image represent the overall perception of the bran and are formed based on the inferences consumers make and the schema consumer associate with the brand ". Artimya adalah citra merek mewakili keleseluruhan persepsi tentang merek dan dibentuk berdasarkan interfaces yang dibuat dan skema dan di asosiasikan oleh konsumen.

" Brand image represent the beliefe consumers associate whit a brand and is an information chunk, It may be compesed of twenty different component but it can be retrived so one general impression ". Artinya adalah bahwa sebuah citra merk mewakili kepercayaan yang diasosiasikan konsumen dengan sebuah merek dan merupakan segumpal informasi. Citra merk mungkin tersusun dari duapuluh komponen yang berbeda tetapi dapat diingat kembali sebagi satu kesan tertentu yang umum atau utuh.

Kotler (2000), menyebutkan bahwa para pembeli mungkin mempunyaitanggapan berbeda terhadap citra perusahaan atau merek. Citra merek adalah persepsi masyarakat terhadap perusahaan atau produknya. Citra dipengaruhi oleh banyak faktor yang di luar kontrol perusahaan. Citra yang efektif akan berpengaruh terhadap tiga hal yaitu : pertama, memantapkan karakter produk danusulan nilai. Kedua, menyampaikan karakter itu dengan cara yang berbedasehingga tidak dikacaukan dengan karakter pesaing. Ketiga, memberikankekuatan emosional yang lebih dari sekadar citra mental. Supaya bisa berfungsicitra harus disampaikan melalui setiap sarana komunikasi yang tersedia dan kontak merek.

Suatu asosiasi merek adalah segala hal yang berkaitan mengenai sebuah merek (Aaker, 1997:160) jadi sesungguhnya sebuah merek adalah seperangkat asosiasi, biasanya terangakai dalam bentuk yang bermakna. Asosiasi itu tidak hanya exis namun juga mempunyai suatu tingkatan kekuatan. Kaitan pada merek akan lebih kuat jika dilandaskan pada banyak pengalaman atau penampakan untuk mengkomunikasikannya.

Kertajaya dalam bukunya Marketing Plus 2000 mengemukakan pentingnya asosiasi merek dimana sebuah merek mungkin memilki kesadaran merek yang tinggi, tetapi asoasiasi merek yang terbentuk dibenak konsumen sangat bervariasi. Selanjutnya dikatakan oleh Kertajaya bahwa asosiasi merek yang terjadi pada non-user sangat penting karena belum ada pengalaman sedikitpun. Asosiasi merek bisa menentukan keberhasialn penjualan kepada mereka. Untuk mendaptkan pelanggan baru, asosiasi yang dimadkan, harus terbentuk secara benar.

\section{Perilaku Konsumen}

Engel (1991:136) mendefinisikan perilaku konsumen sebagai berikut “... those acts individuals directly involved in obtaining and using economics good and services the decisions prosess that proceed and determine these act". Artinya adalah perilaku konsumen adalah tindakan dari individu secara langsung dalm memperoleh dan menggunkan barang ekonomis dan jasa, yang meliputi tindakan pengambilan keputusan yang mendasari dan menentukan tindakan tersebut.

Loudon (1991:5) mendefinisikan perilaku konsumen sebagai berikut " The decision process and physical activity individual engage in when evaluations, acquiring and sevices". Artinya perilaku konsumen adalah proses pengambilan keputusan dan tindakan fisik yang dilakukan oleh individu dalam mengevaluasi, menerima, menggunakan, atau memastikan suatu barang atau jasa.

Dari kedua definisi tersebut dapat disimpulkan bahwa terdapat dua elemen penting dalam perilaku konsumen yaitu mengambil keputusan dan tindakan fisik yang melibatkan individu dalam menilai, mendapatkan, dan menggunakan baraang atau jasa. Konsumen merupakan faktor penentu terhadap kegiatan perekonomian sebuah perusahaan. Hal ini disebabkan karena para konsumen yang dapat mendatangkan penjualan dan keuntungan melalui keputusan pembelian yang mereka buat. Maka dari itu, merupakan suatu hal yang penting bila para manajer suatu perusahaan mengetahui apa dan bagaimana perilaku konsumen dari produk-produk yang mereka jual. Kesadaran akan pentinya perilaku konsumen mengharuskan para pelaku pasar menganalisis faktor-faktor yang mempengaruhi pemilihan oleh konsumen secara lebihy dekat (Engel,1991:149). 
Pemilihan konsumen terhadap suatu produk yang akan dibeli tidak terjadi begitu saja. Hal ini kadang kala melalui suatu proses yang cukup rumit. Salah satu cara yang ditempuh untuk mempengaruhi keputusan konsumen adalah memberikan stimulus primer yang berupa perubahan produk beserta elmenelmennya stimulus skunder melalui penyampaian kata-kata, gambar, symbol yang berkaitan dengan produk yang ditawarkan kepada konsumen. Pemberian stimulus ini berkaitan dengan kegiatan marketing mix yang artinya mempengaruhi persepsi konsumen.

\section{Pengetahuan Produk (Product Knowledge)}

Produk menurut Kotler dan Amstrong (1996:274) adalah : "A product as anything that can be offered to a market for attention, acquisition, use or consumption and that might satisfy a want or need". Artinya produk adalah segala sesuatu yang ditawarkan ke pasar untuk mendapatkan perhatian, dibeli, dipergunakan dan yang dapat memuaskan keinginan atau kebutuhan konsumen.

Menurut Stanton, (1996:222), “A product is asset of tangible and intangible attributes, including packaging, color, price quality and brand plus the services and reputation of the seller". Artinya suatu produk adalah kumpulan dari atribut-atribut yang nyata maupun tidak nyata, termasuk di dalamnya kemasan, warna, harga, kualitas dan merk ditambah dengan jasa dan reputasi penjualannya.

Menurut Tjiptono (1999:95) secara konseptual produk adalah pemahaman subyektif dari produsen atas "sesuatu" yang bisa ditawarkan sebagai usaha untuk mencapai tujuan organisasi melalui pemenuhan kebutuhan dan keinginan konsumen, sesuai dengan kompetensi dan kapasitas organisasi serta daya beli. Berdasarkan fungsinya produk dibedakan menjadi tiga level. Level pertama adalah core product yaitu suatu produk yang fungsinya merupakan alasan dasar konsumen untuk membelinya. Contoh sederhana dari core product adalah pakaian, fungsinya dasarnya untuk melindungi tubuh manusia. Actual product adalah fitur-fitur yang ada pada produk untuk menambah nilainya. Misal desain yang menarik, nama merk, dan kemasan. Augmented product adalah tambahan manfaat-manfaat yang tidak terpikirkan oleh konsumen tapi akan memberi kepuasan bagi mereka, seperti garansi.

Produk juga digolongkan berdasarkan tujuan konsumen membeli barang secara umum. Produk yang dibeli oleh konsumen untuk kepentingan sendiri disebut consumer product. Produk yang dibeli oleh konsumen untuk kepentingan organisasi atau bisnisnya disebut business atau industria product. Produk bisnis bisa dikatakan sebagai produk yang dibeli untuk dijual lagi.

Consumer product dibedakan menjadi empat yaitu:convinience product,shopping product, dan specialty product. Convinience product adalah produk yang sering dibeli langsung, harganya rendah, biasanya kegiatan promosi dilakukan melalui mass advertising. Shopping product adalah produk sekunder yang harganya lebih mahal daripada convenience product. Produk jenis ini digunakan untuk memenuhi kebutuhan sekunder manusia. Dalam proses pembeliannya, orang memerlukan waktu untuk membandingkan baik dengan cara survey maupun tes. Unsought product adalah produk yang sering tidak terpikir untuk dibeli konsumen, contohnya asuransi, tanah kuburan, dan ensiklopedi. Barang industrial dibagi menjadi tiga golongan yaitu bahan baku dan bahan pembantu, bahan pendukung, dan barang modal.

Pengetahuan produk adalah variabel konseptual yang penting dalam perilaku konsumen dan dipengaruhi oleh pengumpulan informasi (Coutler a al, 2005:604). Pengetahuan produk merupakan petunjuk industry yang sangat penting bagi konsumen untuk dipertimbangkan ketika mengevaluasi produk sebelum dilakukan pembelian (Zeithaml dalam Lin \& Lin, 2007:121). Konsumen akan cenderung menggunakan petunjuk intrinsik terlebih dahulu dalam menilai suatu produk,seprti fungsi atau kualitas produk, namun jika petunjuk intrinsik tidak diperoleh dengan benar, maka konsumen akan menggunakan petunjuk ekstrinsik seperti citra merek.

Definisi pengetahuan produk antara lain dikemukakan oleh Beathty \& Smith (1987) daloam Lin \& Lin (200:122) yaitu " product knowledge is a perception consumers have towards certain product, including previous experience of using the product." Brucks (1985) dalam Lin \& Chen (2006:250) menyatakan bahwa "product knowledge is a complex, multidimensional cntruct that is characterizet by the structure and the content of information stored in memory."

Berdasarkan definisi tersebut maka studi ini menyimpulkan bahwa:

1. Pengetahuan konsumen tentang produk didasarka pada persepsi konsumen tentang produk tersebut.

2. Pengetahuan produk dapat berasal dari jumlah, tipe serta organisasi yang menghasilakn suatu produk yang tersimpan dalam memori seseoarang.

3. Pengetahuan konsumen tentang produk dapat pula didasraka pada pengalaman konsumen dalam menggunakan produk. Pengalaman konsumen sepanjang waktu dari pengguna suatu produk akan membuat konsumen lebih familiar tentang produk tersebut.

4. Pengetahuan produk bersifat multidimensional dan sangat komplek sehingga diperlukan suatu pemahaman tentang suatu produk yang didasarkan pada informasi yang diperoleh dan tersimpan pada ingatan konsumen.

5. Sumber utama pengetahuan produk adalah memori, yang jika kemudian dirasakan tidak cukup maka konsumen akan mencari informas yang berasal dari luar.

Konsumen memiliki tingkatan pengetahuan produk yang berbeda dalam memahami informasi 
baru dan membuat pilhan pemberlian. Ada empat tingkatan pengetahuan produk konsumen yaitu:

1. Kelas produk (product class) merupakan tingkat pengetahuan produk yang terus dan didalam termasuk beberapa bentuk produk, beberapa merek dan model dalam katagori tersebut.

2. Bentuk produk (product form) adalah katagori yang lebih luas yang termasuk didalamnya beberapa merek yang seruapa, dan berdasarakan pada karakteristik fisik dari berbagai suaqtu merek.

3. Brand (merek)

4. Dan model atau fitur yang merupakan contoh spisifik dari suatu merek yang memiliki satu atau lebih fitur produk atau atribut yang unik (Peter \& Olson, 2008:69).

Anderson et al (1980) dalam Lin \& Lin (2007:123) membedakan konsumen berdasarakan jenis pengetahuan produk yang memiliki yaitu, (expert) dan pemula atau rang baru (novice). Ahli (exper) tidak perlu mencari informasi tentang banyak produk dan dapat memproses informasi secara efektif serta dapat membedakan berbagai merek dan menentukan kualitasnya. Sedangakan orang baru (novice) menjadiakan serta atau masukan dari orang lain tentang pengetahuan produk kerena kurangnya pengetahuan yang memiliki. Pengetahuan produk konsumen dipengaruhi pemrosesan informasi (Larkit et al (1980) dalam Lin \& Chaen, 2006:250). Konsumen pada umunya akan membuat pilihan setelah mereka memperoleh informasi yang menjadi dasar pengambilan keputusan adalah berbeda. Lin \& Zhen (2005) dalam Lin \& Chen (2006:250) menegaskan bahwa pengetahuan produk bergantung pada kesadaran konsumen atau pengertian tentang produk, atau kepercayaan konsumen terhadap roduk tersebut.

Prak \& Lesig (1981) dalam Lin \& Lin (2007:123) menyatakan bahwa pengetahuan produk konsumen didasarkan pada tingkat kebiasaan (familiarity) terhadap produk. Konsumen dengan pengetahuan produk yang tinggi akan memiliki daya ingat, pengenalan, analisis dan kemampuan logis yang lebih baik daripada konsumen dengan pengetahuan produk yang rendah, sehingga konsumen yang berfikir bahwa mereka memiliki pengetahuan produk yang lebih tinggi akan mempercayakan pada petunjuk intrinsik dalam mempertimbangkan kuailtas produk karena mereka sadar pentingnya informasi tentang suatu produk. Sedangakan konsumen dengan pengetahuan produk yang lebih rendah cenderung menggunakan petunjuk ekstrinsik, seperti harga atau merek untuk mengevaluasi suatu produk karena mereka tidak mengetahui cara menilai suatu produk.

Dari berbagai faktor yang diperhatikan perusahaan dalam menyusun strategi produk tingkat produk individual, tiga diantaranya perlu mendapat perhatian khusus. Ketiga faktor tersebut adalah atribut produk, penggunaan merek dagang, dan kemasan. Sebagian besar perusahaan menghasilkan lebih dari satu seri produk. Tiap seri produk seringkali terdiri lebih dari satu jenis produk. Sayangnya tidak semua seri dan jenis produk memberikan sumbangan hasil penjualan dan keuntungan yang sama. Oleh karena itu, pengelolaan tiap seri dan jenis produk juga tidak sama. Kapasitas produk menyumbang keuntungan ditentukan oleh jumlah satuan produk yang terjual tiap masa tertentu dan besarnya contribution margin. Contribution margin adalah selisih antara harga jual persatuan produk dan biaya variabelnya. Karena berbagai macam alasan perusahaan dapat memutuskan memperluas usaha bisnisnya. Upaya perluasan bisnis tersebut dapat dilakukan dengan memproduksi produk baru dengan mutu, bentuk, ukuran dan harga yang lebih rendah dari produk lama. Strategi menambah jenis produk baru seperti ini disebut downward stretching yaitu memproduksi produk yang mutu, bentuk dan harganya lebih tinggi dari produk lama. Di samping itu perusahaan juga dapat memperluas usahanya dengan jalan product line-filling, yaitu menambah jenis produk bau pada seri-seri produk yang sudah berjalan .

Hal lain yang wajib diperhatikan perusahaan dalam menyusun produk adalah adanya kenyataan bahwa setiap jenis produk mempunyai siklus kehidupan yang terdiri dari empat tahap. Keempat, tahap pertumbuhan, tahap kematangan dan tahap penurunan. Masing-masing tahap siklus kehidupan produk memerlukan strategi pemasaran yang berbeda.

\section{Persepsi Konsumen (Consumer Perception)}

Menurut assael (1995: 185) mendefinisikan persepsi konsumen sebagai berikut: "...the selection, organization, and interpretation of marketing and environmental stimuli into coherent picture". Artinya persepsi konsumen adalah penyelesaian, pengorganisasian, dan penginterpretasian dari rangsangan pemasaran (environmental stimuli) menjadi sebuah gambaran yang jelas. Stimuli adalah semua komunikasi baik fisik, visual, atau verbal yang dapat mempengaruhi seseorang.Jadi, stimuli pemasaran adalah semua komunikasi pemasaran yang dirancangn untuk mempengaruhi konsumen.

Ada dua faktor kunci yang menentukan stimuli, yang mana akan dipersepsikan oleh konsumen dan bagaimana mereka menginterpretasikan stimuli tersebut yaitu karakteristik stimuli itu sendiri dan karakteristik atau kemampuan konsumen untuk mempersepsikan stimuli tersebut. Karakteristik stimuli dapat dibagi dua yaitu sensory elemen dan structural elemen. Sensory elemen terdiri dari warna, bau, rasa, suara dan feel. Sedangkan structural elemen dapat berupa ukuran besar baliho sebuah iklan, posisi produk pada rak-rak toko swalayan, dan yang lainnya yang dapat menarik perhatian konsumen. Karakteristik konsumen yang menentukan persepsi konsumen terhadap stimuli dibagi menjadi dua yaitu kemampuan membedakan antara stimuli dan kecenderungan untuk menggeneralisasikan atau menyamakan antar beberapa stimuli. 
Menurut Kottler dan Amstrong (1997: 40), persepsi adalah proses yang dengan proses itu konsumen memilih, mengorganisasi, dan menginterpretasikan stimuli untuk membentuk gambaran dunia yang penuh arti. Stimuli adalah setiap input yang dapat ditangkap oleh indera, seperti produk, kemasan, merek, iklan, dan lain-lain. Stimuli tersebut diterima oleh panca indra seperti mata, telinga, mulut, hidumg dan kulit.

Menurut Robbins (1996:24) didefinisikan sebgai suatu proses dengan nama individu-individu mengorganisasikan dan menafsirkan kesan-kesan inrda mereka agar memberikan makana bagi lingkungan mereka. Hammer dan Organ yang dikutip oleh Indrawijaya (1986:45) menyatakan bahwa persepsi adalah suatu proses dengan nama seseorang mengorganisasikan dalam pikiranya, menafsirkan, mengalami, dan mengolah pertanda atau segala sesuatu yang terjadi dilingkunganya.

Menurut Schiffman dan Kanuk (2002:122) Perception is defined as the process by which an individual select, organizes and interprets stimuli into a meaningful and coherent picture in the world. It can be described as "how we see the world around us." (Persepsi didefinisikan sebagai proses menyeleksi, mengelompokkan dan menginterpretasikan rangsangan oleh setiap individu menjadi gambaran yang berarti dan koheren, dan dapat dijelaskan sebagaimana kita melihat dunia disekeliling kita). Dua orang yang berbeda, yang dapat rangsangan yang sama belum tentu menginterpretasikanya dengan sama pula, tapi tergantung pada kebutuah, kenginan, nilai, dan harapan masing-masing individu.

Jalaludin (2002:45) menyatakan bahwa persepsi merupakan pengalaman tentang objek, peristiwa atau hubungan-hubungan yang diproleh dari menyimpulkan informasi dan menafsirkan pesan, persepsi sesorang ditentukan oleh faktor personal (internal) dan faktor situasional (eksternal). Winardi (1999:39) yang menyatakan pengertian persepsi sebagai berikut, persepsi adalah kognitif yang dipergunakan seseorang untuk menafsirkan dan memahami dunia sekitarnya.

\section{Niat Beli Konsumen (Purchase Intention)}

Howard, Shay dan Green (1998:28) mendefinisikan niat beli sebagai" the consumer's intention to buy the product" (niat konsumen untuk membeli sebuah produk). Sementara Engel, Blackwell dan Miniard (1994:157) menggambarkan bahwa pembelian merupakan fungsi dari dua faktor, yaitu niat dan pengaruh dari lingkungan atau perbedaan individu.

Niat beli merupakan perilaku yang muncul sebagai respon terhadap objek. Niat beli juga merupakan minat pembelian ulang yang menunjukkan keinginan pelanggan untuk melakukan pembelian ulang (Assael, 1998: 65). Beberapa pengertian dari intention (Setyawan dan Ihwan, 2004: 13) adalah sebagai berikut: Niat beli dianggap sebagai sebuah 'perangkap' atau perantara antara faktor-faktor motivasional yang mempengaruhi perilaku, niat beli juga mengindikasikan seberapa jauh seorang mempunyai kemauan untuk mencoba, niat beli menunjukkan pengukuran kehendak seseorang, niat beli berhubungan dengan perilaku yang terus menerus. Assael (1998:66) mengemukakan bahwa pemasar akan selalu menguji elemen-elemen dari bauran pemasaran yang mungkin mempengaruhi niat beli.

Niat membeli seringkali digunakan untuk menganalisis perilaku konsumen. Sebelum melakukan pembelian, konsumen biasanya akan mengumpulkan informasi tentang produk yang didasarkan pada pengalaman pribadi maupun informasi yang berasal dari lingunganya. Setelah informasi dikumpulkan, maka konsumen akan mulai melakukan penelitian terhadap produk, melakukan evaluasi serta membuat keputusan pembelian setelah membandingkan produk serta mempertimbangakan.

Wu \& Luan (2007:8) menyatakan bahwa niat pembelian digunakan untuk memprediksi perilaku individu, dimana individu lebih suka mendasarkan predeksi mereka pada tingkat dimana mereka benerbener menginginkan untuk mengonsumsi suatu produk. Sedangkan pengertian purchase intention to buy adalah tahap sebelum purchase decision dalam proses pengambilan keputusan pembelian menurut Kotler (2003:207)

Niat pembelian (purchase intention) merupakan perilaku yang muncul sebagai respon terhadap objek. Niat pembelian (purchase intention) juga merupakan niat pembelian ulang yang menunjukkan keinginan pelanggan untuk melakukan pembelian ulang (Assael, 1998) dalam Tony Wijaya. Banyak sekali faktor yang dapat mempengaruhi konsumen utuk pembelian ulang suatu produk yang telah dikonsumsikannya. Faktor yang paling menonjol adalah faktor kepusan yang bukan hanya baerasal dari baiknya kuailtas produk tetapi juga dipengaruhi oleh faktor lain seperti pelayanan pada saat dan sesudah pembelian, cara pembayaran dan lain-lain.

\section{Pengaruh Brand Image terhadap Purchase Intention}

Hal ini menunjukkan sebagian besar pelanggan beranggapan popularitas citra merek sharp yang sangat besar, sebagai akibat memiliki citra yang baik dan memberikan konsistensi akan jaminan kualitas.

Sebagaimana yang dijelaskan oleh Kotler \& Amstrong bahwa merek akan membantu pembeli dalam berbagai cara, di mana nama merek akan membantu konsumen untuk mengidentifikasi produk sehingga dapat merasakan manfaatnya, dan merek akan menjelaskan kualitas produk kepada pembeli. Sedangkan menurut Kotler \& Keller bahwa essensi merekmerupakan janji penjual yang secara konsisten memberikan tampilan, manfaat dan jasa tertentu kepada konsumen. Begitu juga menurut para peneliti bahwa merek dan produk merupakan suatu bagian yang tidak dapat dipisahkan, dimana produk adalah 
sesuatu yang memberikan manfaat fungsional (functional benefit) sedangkan merek adalah suatu nama, simbol, design, atau tanda yang mempertinggi nilai dari produk atau jasa (Farquhar et al., 1989, yang dikutip dalam Myers.

Dalam upaya untuk membangun nilai pelanggan (customer value) dan keunggulan bersaing (Cravens\& Piercy) berpendapat bahwa "the potential contribution of brand strength to building customer valueand competitive advantage". Artinya adalah potensi kontribusi kekuatan merek untuk nilai membangun pelanggandan keunggulan kompetitif. Dalam membangun citra merek yang positif, dapat diciptakan melalui pengalaman langsung dengan produk, informasi yang dikomunikasikan, dengan sumber komersial lainnya, dan melalui mulut-ke-mulut / word-of-mouth), dukungan investasi dari negara pembuat, kecanggihan teknologi peralatan/mesin yang dipakai, dan sebagainya, sehingga persepsi tentang merek akanmelekat dalam ingatan pelanggan (Keller, 1993, yang dikutip dalam Martinez \&Pina).

\section{Pengaruh Product Knowledge terhadap Purchase Intention}

Ketika melakukan pembelian, konsumen sering mengandalkan ingat pribadi atau pengalaman untuk membuat keputusan. Betti and Smith (1987) mendefinisikan pengetahuan produk sebagai konsumen memiliki persepsi terhadap produk tertentu, termasuk pengalaman sebelumnya menggunakan produk tersebut. Brucks (1985) muncul dengan cara untuk mengukur pengetahuan produk berdasarkan pada study sebelumnya: Pengetahuan atau persepsi subjektif. Pengetahuan: tingkat pemahaman konsumen terhadap produk yang disebut Sharp dinilai pengetahuan (Park et al,1992.2) pengetahuan tujuan: tingkat dan jenis pengetahuan produk tehadap niat pembelian.

Studi mengenai perilaku berubah merek telah menjadi perhatian bagi para peneliti selama beberapa tahun terakhir. Alasan yang mendasari perilaku berubah merek dapat menyebabkan menurunnya kinerja pemasaran karena merosotnya tingkat persepsi konsumen.

Penelitian ini difokuskan untuk menganalisis faktor-faktor yang mempengaruhi perilaku berubah merek khususnya pada konsumen benih sayur. Obyek penelitian ini adalah perusahaan pemasok merek produk Known You Seed. Terdapat tiga faktor utama yaitu tingkat pengetahuan produk, tingkat kepuasan konsumen dan pertimbangan pembelian yang dapat mempengaiuhi perilaku berubah merek. Alat analisis yang digunakan dalam penelitian ini adalah Analisis Faktor Konfirmatori dan Structural Equation Modeling.

\section{Pengaruh Consumer Perception terhadap Purchase} Intention

Alper dan Kamins (1995) menyatakan bahwa konsumen pada umumnya memiliki persepsi positif terhadap merek pioneer (merek pertama dan satu kategori produk), bahkan meskipun merek antara citra merek pioner dengan citra giri ideal individu. Persepsi yang positif terhadap merek pioneer ini akan mengarah pada intensi pembelian yang positif.

Yang dijual, dan apa yang mereka berikan pada masyarakat lebih baik dari pada pesainganya. Tanggapan konsumen merupakan sebuah alat penguji untuk sebuah strategi pemasaran perusahaan. Oleh karena itu, pengetahuan mengenai konsumen harus dimasukkan dalam setiap strategi pemasaran. Data mengenai konsumen dapat membantu perusahaan menentukan pasar dan mengidentifikasi tantangan dan kesempatan, serta memastikan bahwa produknya dapat terus bertahan dalam pasar. Salah satu ukuran keberhasilan suatu usaha adalah bagaimana persepsi konsumen dapat meningkatan kepercayaan terhadap suatu produk sehingga mereka mempunyai keinginan membeli yang sangat besar terhadap produk tersebut.

Hal ini dapat diketahui dengan melakukan penilaian persepsi konsumen. Hasil penilaian dapat diukur dengan membandingakan data yang ada dilapangan. Bagi perusahaan hasil penilaian persepsi konsumen sangat penting peranannya dalam pengambilan keputusan berbagai hal terutama dalam hal ini yaitu tentang keputusan pembelian suatu produk atau barang. Konsumen secara selektif memilih stimuli mana yang akan diterima dan menjadikan stimuli tersebut sebagai dasar psikologi utama. Penginterpretasian stimuli juga berbeda-beda pada masing-masing individu. Penginterpretasian stimuli juga berbeda-beda pada masing-masing individu. Proses tersebut terjadi sejak konsumen menangkap stimuli tersebut pertama kali. Penilaian oleh konsumen biasanya dipengaruhi oleh pengalaman maupun referensi yang dimiliki konsumen. Sehingga pengalaman sebelumnya berperan sebagai dasar acuan atau pertimbangan. Orang tidak menerima berbagai stimuli yang mereka pilih dari lingkungan sebagai sensasi yang terpisah, tetapi mereka cenderung mengelompokkannya menjadi kelompok-kelompok dan merasakannya sebagai satu keseluruhan.

Proses tersebut terjadi sejak konsumen menangkap stimuli tersebut pertama kali. Persepsi konsumen terhadap suatu produk akan menjadi pertimbangan konsumen dalam menentukan pilihan produk mana yang akan dibeli. Jika persepsi tersebut tinggi maka konsumen akan tertarik dan mengevaluasi masukanmasukan informasi yang mereka dapat mengenai barang tersebut untuk kemudian membelinya. Untuk menghasilkan persepsi yang tepat bagi konsumen, perusahaan hendaknya memperhatikan kriteria evaluasi kualitas produk atau jasa yang ditawarkan dengan cara terus menerus, karena orang akan melupakan banyak hal yang mereka pelajari namun cenderung akan mengingat informasi yang mendukung pandangan dan keyakinan mereka untuk membeli produk tesebut. 


\section{Penelitian sebelumnya}

Pada bagian ini akan dibahas mengenai hasil dari penilitian sebelumnya yang dilakukan oleh Nan-Hong Lin dari Universitas Tatung, Taiwan (2007) yang berjudul Pengaruh Brand Image dan Pengetahuan Produk pada Niat Pembelian Diskon Harga yang dilakukan di Taiwan.

Hasil Penelitian :

1. Ada perbedaan yang signifikan dalam korelasi antara citra merek dan niat pembelian. Kesimpulan ini menunjukkan bahwa niat beli konsumen tidak mendapatkan dipengaruhi oleh citra merek. Semakin tinggi status dari citra merek, niat pembelian lebih ada.

2. Ada perbedaan yang signifikan dalam korelasi antara pengetahuan produk dan niat pembelian. Jelas, niat pembelian konsumen dipengaruhi oleh jumlah produk pengetahuan yang lebih tinggi.

3. Dengan potongan harga sebagai moderator, ada perbedaan yang signifikan antara citra merek dan pembelian niat.

Persamaan penelitian sekarang dengan penelitian terdahulu yaitu sama-sama menggunakan Teknik Analisis Regresi Linier berganda dan sama-sama meneliti Brand Image dan Pengetahuan Produk pada Niat Pembelian.

Perbedaan pada obyek penelitian terdahulu yaitu masyarakat di taiwan Pembelian Diskon Harga, sedangkan penelitian sekarang yaitu masyarakat di Menganti-Gresik Purchase Intenton.

\section{METODE PENELITIAN}

Adapun objek penelitian ini di wilayah Gresik. Lokasi penelitian yaitu di Kecamatan Menganti Gresik. Populasi dalam penelitian ini adalah masyarkat di Kecamatan Menganti yang mengetahui dari merek Sharp tapi belum pernah melakukan pembelian.Adapun sampel yang digunakan adalah teknik Accidental Sampling Technique yaitu teknik penentuan sampel berdasarkan kebetulan, yaitu siapa yang kebetulan bertemu dengan peneliti dapat digunakan sebagai sampel, bila dipandang orang yang kebetulan ditemui itu cocok sebagai sumber data (Sugiyono, 2005;60). Dalam penelitian ini sampel yang akan diambil sebesar 100 Responden dari semua Konsumen lemari es merek Sharp yang ada di Kecamatan Menganti Gresik.

\section{Definisi Operasional}

Penelitian ini terdiri dari, variabel bebas yang meliputi Brand Image $\left(\mathrm{X}_{1}\right)$, Product Knowledge $\left(\mathrm{X}_{2}\right)$, Consumers perceptions $\left(\mathrm{X}_{3}\right)$ dan variabel terikat yaitu Purchase Intention(y). Maka definisi operasional yang diajukan dari variabel-variabel adalah sebagai berikut:

1. Variabel $\mathrm{X}_{1}$ : Brand ImageyaituKonsumen percaya bahwa lemari es merek Sharp memiliki manfaat bagi mereka.
2. Variabel $\mathrm{X}_{2}$ : Product Knowledge yaituPengetahuan produk lemari es merek Sharp yang ada untuk meyakinkan para konsumen.

3. Variabel $\mathrm{X}_{3}$ :Consumers perceptionsyaitu Persepsi konsumen terhadap lemari es merek Sharp yang akan di pandang lain

4. Variabel Y : Purchase Intention adalah suatu proses pengambilan niat akan pembelian yang mencakup penentuan apa yang akan dibeli atau tidak melakukan pembelian dan keputusan itu diperoleh dari kegiatan - kegiatan sebelumnya.

Metode analisis yang digunakan dalam penelitian ini adalah regresi linier berganda. Analisis linier berganda ini digunakan untuk mengetahui adanya pengaruh antara variabel terikat yaitu Niat bembelian (Y) dengan variabel-variabel bebas yaitu Brand Image $\left(\mathrm{X}_{1}\right)$, Product Knowledge $\left(\mathrm{X}_{2}\right)$, Consumer Perceptions $\left(\mathrm{X}_{3}\right)$.

Rumus yang digunakan adalah:

$$
\mathrm{Y}=\mathrm{a}+\mathrm{b}_{1} \mathrm{X}_{1}+\mathrm{b}_{2} \mathrm{X}_{2}+\mathrm{b}_{3} \mathrm{X}_{3}+\mathrm{e}
$$

Keterangan : $\mathrm{Y}=$ Purchase Intention

$$
\begin{aligned}
& \mathrm{a}=\text { Konstanta } \\
& \mathrm{b}_{1} \mathrm{~b}_{2} \mathrm{~b}_{3}=\text { Koefisien Regresi } \\
& \mathrm{X}_{1}=\text { Brand Image } \\
& \mathrm{X}_{2}=\text { Product Knowledge } \\
& \mathrm{X}_{3}=\text { Consumer Perceptions } \\
& \mathrm{e}=\text { Variabel Penggangu }
\end{aligned}
$$

Pengukuran variabel adalah penunjukan angkaangka pada suatu variabel menurut aturan yang telah ditentukan. Dengan penelitian ini pengukuran atas indikator atau variabel-variabel dengan menggunakan skala Likert yang menunjukkan bobot nilai sebagai berikut:

1. Responden akan mendapat nilai 5 apabila responden menjawab A jika sangat percaya.

2. Responden akan mendapat nilai 4 apabila responden menjawab $\mathrm{B}$ jika percaya.

3. Responden akan mendapat nilai 3 apabila responden menjawab $\mathrm{C}$ jika cukup percaya.

4. Responden akan mendapat nilai 2 apabila responden menjawab D jika tidak percaya.

5. Responden akan mendapat nilai 1 apabila responden menjawab $\mathrm{E}$ yaitu jika sangat tidak percaya.

\section{Uji Asumsi Klasik}

Persamaan regresi yang diperoleh dari analisis data harus menghasilkan estimator linear tidak terbatas atau bersifat BLUE (Best Linear Unbias Estimator) sehingga dalam pengambilan keputusan yang BLUE maka harus dipenuhi beberapa simulasi.

\section{Autokorelasi}

Adalah suatu korelasi antara nilai variabel dengan nilai variabel yang sama pada lagi satu atau lebih sebelumnya. (Bambang, 2007:93). Definisi yang lain adalah terdapat pengaruh dari variabel dalam model melalui tenggang waktu. Hal ini berarti bahwa nilai variabel saat ini akan berpengaruh pada nilai variabel dimasa yang akan datang. Jika dalam model regresi 
terdapat autokorelasi maka akan menyebabkan varians sampel tidak dapat menggambarkan varians populasinya dan model regresi yang dihasilkan tidak dapat digunakan untuk menaksir nilai variabel independen tertentu.

Untuk mendiagnosis ada tidaknya autokorelasi dalam suatu model regresi dapat dilakukan dengan cara melakukan pengujian terhadap nilai uji Durbin -Watson (DW). Pengambilan keputusan ada tidaknya autokorelasi adalah sebagai berikut :

1. Bila nilai DW terletak diantara batas atas (du) dan (4-du), maka koifisien autokorelasi sama dengan nol berarti tidak ada autokorelasi.

2. Bila nilai DW lebih rendah daripada batas bawah (dl), maka koifisen autokorelasi lebih bessar daripada nol, berarti ada autokorelasi positif.

3. Bila nilai DW lebih besar daripada (4-dl), maka koifisen autokorelasi lebih kecil daripada nol, berarti ada autokorelasi negatif.

4. Bila nilai DW terletak diantara baris atas (du) dan batas bawah (dl) atau DW terletak antara (4-du) dan (4-dl) maka hasilnya tidak dapat disimpulkan.

\section{Multikolinearitas}

Multikolinearitas Adalah variabel independen yang satu denngan independen yang lain dalam model regresi saling berhubungan secara sempurna atau mendekati sempurna. Apabila dalam model regresi terdapat multikolinearitas maka akan menyebabkan kesalahan estimasi akan cenderung meningkat dengan bertambahnya variabel independen, tingkat estimasi yang digunakan untuk menolak hipotesis nol akan semkin besar dan probabilitas menerima hipotesis yang salah juga semakin besar,hal ini akan mengakibtakan model regresi yang diperoleh tidak valid untuk menaksir nilai variabel independen. Model regresi yang baik seharusnya tidak mengandung korelasi diantara variabel independen.Untuk mendeteksi ada tidaknya multikolinearitas dapat dilihat dari nilai tolerance value dan value inflation (VIF). Apabila nilai tolerance value $<0,10$ dan VIF $>10$ maka terjadi multikolinearitas. Jika nilai tolerance value $>0,10$ dan VIF kurang dari 10 maka tidak terjadi multikolinearitas.

\section{Heteroskedastisitas}

Artinya varians variabel dalam model tidak sama (konstan), hal ini bisa diidentifikasi dengan cara melakukan uji Glesjer, yaitu dengan meregresikan nilai absolute residual terhadap seluruh variabel bebas mempunyai $\mathrm{t}$ hitung yang tidak signifikan maka dapat dikatakan bahwa model dalam penelitian lolos dari adanya heteroskedastisitas.

\section{HASIL DAN PEMBAHASAN} Uji Validitas

Uji Validitas digunakan untuk mengukur sah atau validnya suatu kuesioner. Suatu kuesioner dikatakan valid jika mampung mengukur yang di inginkan serta dapat mengungkapkan data dari variabel yang di teliti secara cepat dalam uji validitas berdasarkan butir pertanyaan atau variabel dinyatakan valid jika $r_{\text {hasil }}>r$ table (Santoso, 2001;280).

\section{Uji Reliabilitas}

Uji reliabilitas (kehandalan) adalah nilai yang menunjukan sejauh mana suatu alatb pengukut dapat dipercaya dan dapat diandalkan (konsisten). Dalam uji reliabilitas ini suatu butir atau variabel dikatakan reliabel jika $\mathrm{r}_{\text {alpha }}>\mathrm{r}$ table (Santoso, 2001;280).

\section{Uji Autokorelasi}

Dalam penelitian ini besarnya durbin watson setelah dianalisis adalah 2,001. Untuk mengatahui gejala autokorelasi maka perlu dilihat tabel durbin watson dengan jumlah variabel bebas $\mathrm{k}=3$, sedangkan jumlah pengamatan 100 maka diperoleh $\mathrm{dl}=1,61$ dan $\mathrm{du}=1,74$.

\section{Uji Multikolinieritas}

Uji multikolinieritas digunakan untuk mengetahui ada atau tidaknya multikolonierotas yaitu dengan melihat besarnya nilai VIF yang diperoleh. Toleransi mengukur variabilitas variabel bebas yang terpilih yang tidak dapat dijelaskan oleh variabel lainya. Nilai toleransi yang umum dipakai adalah 0,10 atau sama dengan nilai VIF dibawah 10. Maka terjadi multikolonieritas (Ghozali:2002:57).

\section{Uji Heteroskedaskisitas}

Uji heteroskidaskisitas digunakan untuk mengetahui ada atau tidaknya penyimpangan asumsi klasik heteroskidaskisitas, yaitu adanya ketidaksamaan Varian dari residual untuk semua pengamatan pada model regresi.

\section{ANALISIS DATA}

Analisis data yang digunakan dalam penelitian ini adalah regresi linier berganda dengan Purchase Intention (Y) sebagai variabel terikat.Variabelvariabel bebasnya adalah Brand Image $\left(\mathrm{X}_{1}\right)$, Product Knowledge $\left(\mathrm{X}_{2}\right)$ danConsumers perceptions $\left(\mathrm{X}_{3}\right)$.

\section{Analisis Regresi Linear Berganda}

Analisis Regresi Linier Berganda ini digunakan untuk mengetahui adanya pengaruh Variabel Bebas yaitu, Kepribadian Merek dimensi ketulusan, kegembiraan, kemampuan, pengalaman, kekasaran terhadap variabel terikat yaitu keputusan pembelian, maka peneliti menggunakan regresi linier berganda dan pengolahanya dilakukan dengan menggunakan program SPSS 15.00 for windows.

Persamaan regresi berganda adalah sebagai berikut :

$$
\mathrm{Y}=2,913+0,156 \mathrm{X} 1+0,159 \mathrm{X} 2+0,175 \mathrm{X} 3+\mathrm{e}
$$

Dari persamaan regresi linier berganda, maka dapat dijelaskan sebagai berikut : 
Koefisiensi konstanta "a" atau $\left(\beta_{0}\right)$ sebesar 2,913 menyatakan bahwa jika Purchase Intentionnaik sebesar 2,913 dengan asumsi X1, X2, X3 sama dengan nol.

1. Koefisien regresi $X_{1}$ sebesar 0,156 menyatakan bahwa Brand Image berubah satu satuan dan variabel lain konstan, maka nilai Purchase Intention berubah 0,156 satuan.

2. Koefisien regresi $X_{2}$ sebesar 0,159 menyatakan bahwa variabel Product Knowledge berubah satu satuan dan variabel lain konstan, maka nilai Purchase Intention berubah 0,159 satuan.

3. Koefisien regresi $X_{3}$ sebesar 0,175 menyatakan bahwa variabel kualitas Consumer Perception berubah satu satuan dan variabel lain konstan, maka nilai Purchase Intention berubah 0,175 satuan.

\section{Pengujian Hipotesis}

Hipotesis penelitian ini adalah ada pengaruh secara parsial dan secara simultan atau bersama-sama variabel Brand Image $\left(\mathrm{X}_{1}\right)$, Product Knowledge $\left(\mathrm{X}_{2}\right)$, Consumers perceptions $\left(\mathrm{X}_{3}\right)$ terhadap Purchase Intention(y). Pengujian hipotesis dilakukan dengan teknik statistik uji t (parsial) dan uji F (simultan).

\section{Uji t (Parsial)}

Uji t digunakan untuk melihat pengaruh masingmasing variabel bebas secara parsial terhadap variabel terikat.

Jika $-\mathrm{t}$ tabel $\leq \mathrm{t}$ hitung $\leq \mathrm{t}$ tabel maka $\mathrm{H}_{0}$ diterima

Jika $\mathrm{t}$ hitung <-t tabel atau $\mathrm{t}$ hitung $>\mathrm{t}$ tabel maka $\mathrm{H}_{0}$ ditolak

Hipotesis penelitian :

1) Variabel $X 1$ (Brand Image)

Berdasarkan perhitungan diperoleh $\mathrm{t}$ hitung sebesar 2,025 lebih besar dari t tabel sebesar 1,9847.

Karena t hitung > t tabel yaitu 2,055 > 1,9847, maka Ho ditolak dan $\mathrm{H}_{1}$ diterima. Berarti Brand Image $\left(\mathrm{X}_{1}\right)$ berpengaruh positif signifikan terhadap Purchase Intention lemari es merek Sharp di kecamatan Menganti Gresik.

\section{2) Variabel X2 (Product Knowledge)}

Berdasarkan perhitungan diperoleh $\mathrm{t}$ hitung sebesar 2,402 lebih besar dari t tabel sebesar 1,9847

Karena $\mathrm{t}$ hitung > t tabel yaitu 2,402>1,9847, maka Ho ditolak dan $\mathrm{H}_{1}$ diterima. Berarti Product Knowledge (X2) berpengaruh positif signifikan terhadap Purchase Intention lemari es merek Sharp di kecamatan Menganti Gresik.

3) Variabel X3 (Consumer Perception)

Berdasarkan perhitungan diperoleh $\mathrm{t}$ hitung sebesar 2,489 lebih besar dari t tabel sebesar 1,9847.

Karena t hitung > t tabel yaitu 2,489> 1,9847, maka $\mathrm{H}_{0}$ ditolak dan $\mathrm{H} 1$ diterima. Berarti Consumer Perception (X3) berpengaruh positif signifikan terhadap Purchase Intention lemari es merek Sharp di kecamatan Menganti Gresik.

\section{Uji Simultan (Uji F)}

Untuk pengujian secara simultan antara variabel bebas terhadap variabel terikat dipergunakan uji $\mathrm{F}$, berikut ini beberapa tahap pengujian hipotesis dengan pengujian uji $\mathrm{F}$.

1. Tingkat signifikasi $(\alpha) 0,05=5 \%$ dengan $\mathrm{df}$ pembilang $=\mathrm{k}=3$ dan df penyebut $=\mathrm{n}-\mathrm{k}-1=$ 96 adalah 2,699 (Lampiran 6).

2. Kriteria yang dipakai dalam uji $\mathrm{F}$ adalah:

a. Apabila $\mathrm{F}$ hitung $\geq \mathrm{F}$ tabel, berarti $\mathrm{H}_{0}$ ditolak dan $\mathrm{H} 1$ diterima, artinya secara simultan variabel bebas mempunyai pengaruh yang nyata terhadap variabel terikat.

b. Apabila $\mathrm{F}$ hitung $<\mathrm{F}$ tabel, berarti $\mathrm{H}_{0}$ diterima H1 ditolak, artinya secara simultan variabel bebas tidak mempunyai pengaruh yang nyata terhadap variabel terikat.

1. Dalam pengujian hipotesis secara parsial dengan menggunakan uji $\mathrm{t}$ antara masing-masing antara variabel bebas dan variabel terikat yaitu:

a. Brand Image $(\mathrm{X} 1)$

Brand Imagesecara parsial berpengaruh positif terhadap Purchase Intentionsehingga teoriBrand Image dalam Kotler (2000), menyebutkan bahwa para pembeli mungkin mempunyai tanggapan berbeda terhadap citra perusahaan atau merek. Citra merek adalah persepsi masyarakat terhadap perusahaan atau produknya. Citra dipengaruhi oleh banyak faktor yang di luar kontrol perusahaan. Citra yang efektif akan berpengaruh terhadap tiga hal yaitu : pertama, memantapkan karakter produk danusulan nilai. Kedua, menyampaikan karakter itu dengan cara yang berbeda sehingga tidak dikacaukan dengan karakter pesaing. Ketiga, memberikan kekuatan emosional yang lebih dari sekadar citra mental. Supaya bisa berfungsi citra harus disampaikan melalui setiap sarana komunikasi yang tersedia dan kontak merek, dimana sebagian besar responden setuju terhadap Brand Image.

\section{b. Product Knowledge (X2)}

Product Knowledgesecara parsial berpengaruh positif terhadap Purchase Intentionsehingga teori Menurut Tjiptono (1999:95) secara konseptual produk adalah pemahaman subyektif dari produsen atas "sesuatu" yang bisa ditawarkan sebagai usaha untuk mencapai tujuan organisasi melalui pemenuhan kebutuhan dan keinginan konsumen, sesuai dengan kompetensi dan kapasitas organisasi serta daya beli. Menurut Stanton, (1996:222), "A product is asset of tangible and intangible attributes, including packaging, color, price quality and brand plus the services and reputation of the seller". Artinya suatu produk adalah kumpulan dari atribut-atribut yang nyata maupun tidak nyata, termasuk di dalamnya kemasan, warna, harga, kualitas dan merk ditambah dengan jasa dan reputasi penjualannya, dimana sebagian besar responden setuju terhadap Product Knolwledge.

c. Consumer Perception(X3) 
Consumer Perception secara parsial berpengaruh positif terhadap Purchase Intentionsehingga teorimenurut Robbin (1996:124) Persepsi adalah suatu prosesdimana individu-individu mengorganisasikan dan menafsirkan kesan inderamereka agar memberi makna kepada lingkungannya. Persepsi tidak hanya tergantung pada karakteristik fisik tetapi jugakepada hubungan tersebut dengan lingkungan sekitar dan kondisi dalam diri individu, dimana sebagian besar responden setuju terhadap Consumer Perception.

2. Brand Image, Product Knowledge, Consumer Perception berpengaruh secara simultan terhadap Purchase Intetion Lemari es merek Sharp di kecamatan Menganti Gresik. Teori ini diungkapkan oleh Kotler \& Amstrong bahwamerek akan membantu pembeli dalam berbagai cara, dimana nama merek akan membantu konsumen untuk mengidentifikasi produk sehingga dapat merasakan manfaatnya, dan merek akan menjelaskan kualitas produk kepada pembeli.

\section{SIMPULAN}

Setelah dilakukan pengujian berdasarkan hasil penelitian yang dilakukan tentang analisis pengaruh brand image, product knowledge dan consumer perception terhadap purchase intention lemari es merek sharp di kecamatan Menganti Gresik, bedasarkan dari analisis regresi linier berganda dapat disimpulkan sebagai berikut:

1) Variabel brand image (X1) berpengaruh positif terhadap purchase intention lemari es merek sharp di kecamatan Menganti Gresik

2) Variabel product knowledge (X2) berpengaruh positif terhadap purchase intention lemari es merek sharp di kecamatan Menganti Gresik

3) Variabel perception consumer (X3) berpengaruh positif terhadap purchase intention lemari es merek sharp di kecamatan Menganti Gresik

4) Variabel brand image, product knowledge, dan perception consumer berpengaruh secara simultan terhadap purchase intention lemari es merek sharp di kecamatan Menganti Gresik

\section{Saran}

Berdasarkan pada hasil penelitian dan hasil perhitungan yang diperoleh maka dapat disimpulkan saran - saran sebagai berikut:

1. Bedasarkan hasil penelitian Brand Image berpengaruh terhadap Purchase Intention, maka PT. Sharp Electronics Indonesia memberikan merek yang terkenal dan meningkatkan kualitas serta inovasi baru, begitu juga menawarkan harga yang relatif terjangkau, sehingga memberiakn mafaat tinggi bagi konsumen.

2. Berdasarkan hasil penelitian Product Knowledge berpengaruh terhadap Purchase Intention, maka PT. Sharp Electronics Indonesia mempunyai kualitas atau dalam pemakaian listrik yang hemat, dan mempunyai penampilan model yang bervariasi.

3. Berdasarkan hasil penelitian Conumer Perception berpengaruh terhadap Purchase Intention, maka PT. Sharp Electronics bisa memberikan pengoperasian yang mudah dan harga purna jual yang stabil.

4. Berdasarkan Uji korelasi parsial dapat diketahui bahwa variabelBrand Image, Product Knowledge, Conumer Perceptionmemiliki pengaruh yang lebih besar dibandingkan dengan variabel yang lainya. Maka dengan ini peneliti merekomendasikan untuk lebih memperhatikan variabel ini karena variabel ini sangat lebih berpengaruh dengan Purchase Intentiondibandingkan dengan variabel lain

\section{DAFTAR PUSTAKA}

Aaker, David. 1991. Managing Brand Equity, Capitalyzing on the Value of a Brand Name. The Free Press:New York.

Aaker, David. 1996. Building Strong Brands. New York: The Free Press.

Assael, 1995.Citra Merek.Jakarta: PT Prenhalindo Indonesia.

Betti and Smith SM. 1987. External Search Effort: An Investigation Acroos Several Product Categoris, Journal of Cunsomer Research 14 (1), 83-95

Brucks, M. 1985. The Effect of Product Class Knowledge on Information Search Beavior Journal of Customer Research 12 (1), 1-16

Camilia, Zahrah. 2007. Analisis perilaku perluasan merek terhadap citra merek produk perluasan dengan citra merek indonesia sebagai variabel intervening pada merek filma. Yogyakarta.

Engel, James F. 1991. Perilaku Konsumen Jilid 1. Jakarta: Binarupa Aksara.

Jalaludin. 2002. Chenical Abstracts, American Chemical Society. Chemical Abstracts Service.

Kotler Philip. 1994.Marketing Management; Analysis, Planning,Implementation and Control, Eighth Edition. , 2002. Manajemen Pemasaran Jilid I (edisi Bahasa Indonesia). Jakarta: PT Prenhalindo Indonesia.

Kurnia A, Dimas, 2010. Persepsi Konsumen tentang Promotion Mix dan Keputusan Pembelian Rokok Merek “ $X$ ”, Jurusan Manajemen-STIE Pertiwi. Jakata Selatan.

Lin, Bih-Shya, 2007. Pengaruh Brand Image dan pengetahuan Produk pada Niat Pembelian Diskon Harga. Taiwan: Tatung University.

Lin \& Lin, 2007. Pengetahuan Produk. Taiwan: Tatung University.

Mochtar, M., 2000. Pengantar Metodologi Penelitian. Jakarta: Institut Ilmu Pemerintahan Press.

Schiffman dan Kanuk. 2002. Peception is defined as the process by which an individual selet. Jakarta: Binarupa Aksara. 
, 2008. Perilaku Konsumen Edisi. 7. PT. Indeks: Jakarta.

Sugiyono, 2008. Metode penelitian Bisnis Cetakan kesebelas. Bandung: CV Alfabeta.

Suprapto,1997,"SPSS Versi 17: Mengolah Data Statistik Secara Profesional", Jakarta: PT Gramedia

Surianto, Moh. Agung, Wahdah Dewi W, 2010. Pengaruh Karakteristik Selebriti Endoser terhadap Citra Merek Produk. Gresik: Universitas Muhammdiyah Gresik.

Suryani, Tatik. 2008. Perilaku Konsumen. Yogyakarta: Graha Ilmu.

Susanti, Sulis. 2010. Pengaruh Product Knowledge dan Brand Image terhadap Purchuse Intention Produk NotBook Acer di Kecamatan Gresik. Gresik: Universitas Muhammadiyah Gresik.

Tjiptono, Fandy. 1999. Strategi Pemasaran. Yogyakarta: Andi.

Widjanarko, Hendro. 2005. Pengaruh Dimensi Ekuitas Merek terhadap Niat Membeli'.Universitas Pembangunan Nasional "Veteran" Yogyakarta.

www suaramerdeka.com/2012, Omzet lemari es Sharp Indonesia.

www.radarcirebon.com/2010, Jumlah pelanggan

lemari es Sharp Indonesia

www.anneahira.com/2012, Sejarah PT. Sharp

Indonesia 